\title{
Analisis Strategi Bisnis untuk Mencapai Keunggulan Kompetitif di UMKM Nukida Jati Bojonegoro
}

\section{Analysis of Business Strategies to Achieve Competitive Advantages in MSME Nukida Jati Bojonegoro}

\author{
Ika Munawaroh1, Elva Nuraina1, Elly Astuti1,* \\ 1)Program Studi Pendidikan Akuntansi, FKIP, Universitas PGRI Madiun, Madiun, Indonesia \\ *Coresponding Email: ellyastuti@unipma.ac.id
}

\begin{abstract}
Abstrak
Penelitian ini memiliki tujuan untuk mengidentifikasi strategi bisnis apa yang diterapkan oleh UMKM Nukida Jati agar memilki keunggulan bersaing. Metode penelitian menggunakan kualitatif deskriptif. Sumber data yang digunakan yaitu sumber data primer dan sekunder. Teknik Pengumpulan data wawancara, observasi, dan dokumentasi. Teknik analisis data menggunakan reduksi data, penyajian data informasi dan menarik kesimpulan. Hasil perhitungan matrik IFE (faktor internal) dan EFE (faktor eksternal) menunjukkan bahwa UMKM Nukida Jati berada pada kuadran satu. Kombinasi matriks tersebut dalam analisis SWOT, menunjukkan bahwa posisi perusahaan memungkinkan untuk memaksimalkan peluang dan kekuatan yang dimilikinya. Alternatif strategi bisnis yang dapat diterapkan pada UMKM Nukida Jati pada posisi ini adalah diversifikasi terkait, karena strategi bisnis tersebut memungkinkan perusahaan untuk memproduksi berbagai macam kerajinan tangan dengan spesifikasi yang berbeda sesuai permintaan konsumen dengan bahan baku yang sama. Diversifikasi produk yang berbeda dapat menciptakan peluang pasar yang lebih luas, apalagi jika ditambahkan dengan dukungan digital marketing yang memadai.
\end{abstract}

Kata Kunci: Analisis SWOT, Strategi Bisnis, UMKM, Keunggulan Kompetitif.

\begin{abstract}
This study aims to identify business strategies implemented by MSMEs Nukida Jati to have a competitive advantage. The research method uses descriptive qualitative. Sources of data used are primary and secondary data sources. The technique of collecting data is the interview, observation, and documentation. Data analysis techniques used data reduction, presenting information data, and drawing conclusions. The calculation results of the IFE (internal factors) and EFE (external factors) matrices show that Nukida Jati MSMEs are in quadrant one. Combining these matrices in the SWOT analysis shows that the company's position allows it to maximize the opportunities and strengths. An alternative business strategy that can be applied to Nukida Jati MSMEs in this position is related diversification. This business strategy allows the company to produce various kinds of handicrafts with different specifications according to consumer demand with the same raw materials. Further product diversification can create wider market opportunities, especially if added with adequate digital marketing support.
\end{abstract}

Keywords: SWOT Analysis, Business Strategy, MSME, Competitive Advantage.

How to Cite: Munawaroh, I., Nuraina, E. \& Astuti, E. (2021). Analisis Strategi Bisnis Untuk Mencapai Keunggulan Kompetitif di UMKM Nukida Jati Bojonegoro. JKBM (Jurnal Konsep Bisnis dan Manajemen). 7 (2): 117-126 
Munawaroh, I., Nuraina, E. \& Astuti, E. (2021). Analisis Strategi Bisnis Untuk Mencapai Keunggulan Kompetitif ...

\section{INTRODUCTION}

Business strategy is a direction of action or a series of decisions to help achieve goals. The business strategy combines all management decisions to gain a competitive advantage in the market. This strategy is a long-term plan that becomes a reference or guideline in carrying out all operational activities.

With increasing competition, business strategy is essential for the design and development of business sustainability. Business strategy is part of the design of a business. When determining the business strategy design objectives, it is necessary to know the strengths and weaknesses of the company. If each step is designed, each source will be devoted so that business activities will automatically become more effective and efficient. Business strategy refers to the business strengths used and utilized to gain an edge in business competition in the right way. The competitive advantage can be achieved through quality control. Tight control starting from product planning, production processes to products to customers.

MSMEs must also prioritize competitive advantage. Bojonegoro is one of the districts with many MSMEs that utilize natural resources in the form of teak. Nukida Jati produces teak wood handicrafts in various shapes, designs, and varieties in Batokan Village, Kasiman District, Bojonegoro Regency. MSME Nukida Jati also faces multiple problems in running its business, both from internal and external conditions. Lack of human resources, less than optimal production capacity, inaccurate recording of financial re- ports, and competitors' numbers are also problems for Nukida MSMEs.

The fluctuating economic situation also affects product prices, so it needs the right way to survive in business. Knowing its status can help decide the right strategy based on internal and external conditions. The references of this research are Umar et al. (2016), which state that by conducting a SWOT analysis, to achieve competetive advantage. This is in line with Abdillah et al. (2017), who show that MSMEs have carried out porter's generic strategy well. Likewise, Januarwati \& Poernomo (2014) state that using a SWOT analysis would support selecting strategies to implement aggressive growth policies.

Several studies have documented that differrent industry segments will produce other strategic policies depending on the firm's combined internal and external matrices when performing the SWOT analysis. Umar et al. (2016) and Januarwati \& Poernomo (2014) document that maximizing the strengths and opportunities is the best choice when a company is in quadrant I. Meanwhile, when the company is in quadrant 4, the company must suppress its threats and weaknesses (Hidayat, 2016).

However, Abdillah et al. (2017) revealed that every MSMEs must focus on being achieved. Even though it is in the same quadrant position, it is likely to produce different strategic policies. Sari \& Suprapto (2018) show that companies are implementing a future integration strategy, Januarwati \& Poernomo (2014) show a market development strategy, while Umar et al. (2016) using market penetration. This condition supports Rahmanto \& Rahayu (2017) state that 
when a company is in quadrant one; it can implement a strategy; market development, market penetration, product development, forward integration, backward integration, and backward integration horizontal integration, and related diversification. For this reason, this study was conducted to broaden the insight regarding the company's strategy selection policy based on its quadrant position using a SWOT analysis. This research is expected to contribute to selecting company strategies under the internal and external environments it faces.

\section{RESEARCH METHODS}

The research method is descriptive qualitative research-initial observations at MSME Nuki-da Jati Bojonegoro. Furthermore, Nukida Jati employees and consumers will be interviewed to analyze business strategies to achieve a competitive advantage in Nukida Jati Bojonegoro MSMEs. The research data is in the form of primary data, namely interviews and preliminary observations. Secondary data are supporting documents. Data collection techniques used interviews, observation, and documentation, while data analysis techniques began with data reduction, presenting information data, and draw-ing conclusions. The results of the interview can be accepted and tested using triangulation techniques.

\section{RESULTS AND DISCUSSION}

Nukida Jati MSMEs are growing, but Nukida Jati also faces obstacles. The owner of Nukida Jati has not thoroughly followed technology development to market their products, so the marketing has not been maximized. The expertise of human resources in producing handicrafts is still low, so that at the beginning of the business, there were not too many types of products made. However, until now, Nukida Jati MSMEs have progressed. Nukida Jati MSMEs can produce more than 500 handicraft products in one week. There are various models and designs for clocks, tissue boxes, drink holders, trays, jars, wall hangings, lamps, miniature vehicles, etc.
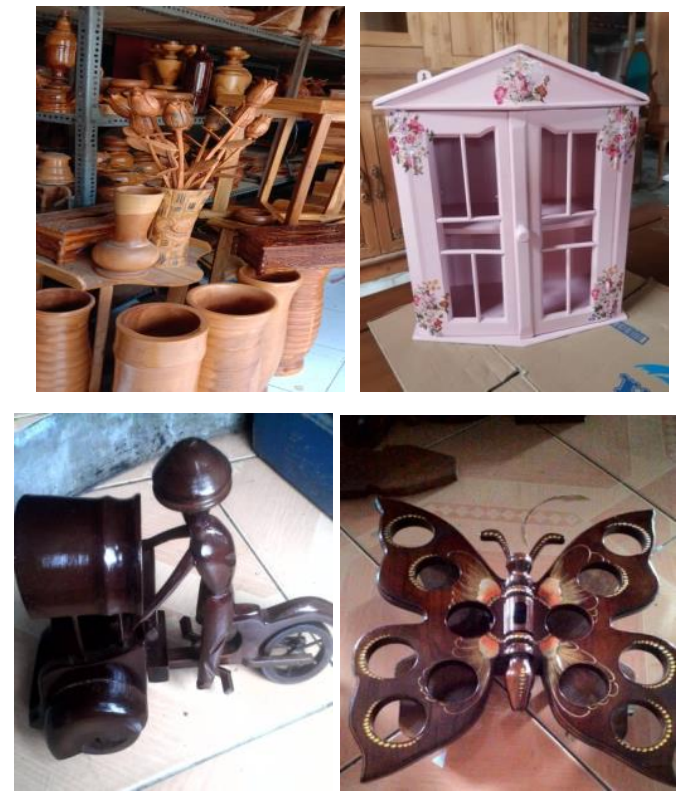

Figure 1 Nukida Jati MSMES Products

The prices for Nukida Jati products range from Rp. 25,000 to Rp. 500,000. Nukida Jati innovates products from shape, size, type, and color. The marketing is also expanding. Once a week, MSMEs Nukida Jati sends goods to Jepara, Surabaya, Jakarta, and Bali. As the business grows, many similar enterprises continue to emerge. This is a threat to Nukida Jati MSMEs in running their business. Until now, Nukida Jati MSMEs, while maintaining product quality, will still attract consumer interest in their products. The problem of limited capital causes MSMEs Nukida Jati to experience obstacles in increasing 
Munawaroh, I., Nuraina, E. \& Astuti, E. (2021). Analisis Strategi Bisnis Untuk Mencapai Keunggulan Kompetitif ...

production capacity to meet demand. Also, MSME Nukida Jati does not have a financial report book. The recording system only uses sales notes, so there is no financial report.

Like any business in general, a craft business also requires careful planning. The planning carried out by Nukida Jati MSMEs is not optimal. It does not have a target and is not well documented. Teak Nukida MSMEs rarely evaluate their business in financial performance, product innovation, and other performance. Nukida Jati MSMEs make products to follow the latest market trends and demands. Creating new product designs is done when there is a decrease in demand for available products.

"All models depend on market demand; as long as they are still in demand, they will still make $i t$, then later when it is a bit decreased, then make more designs."

The statement from Mr. A also supports this statement as the artisan of Nukida Jati:

"There are many problems with that model, miss. The shape of the color depends on the request. "

Product sales are an indicator of the success or failure of a company in implementing a strategy. Nukida Jati sells to various groups, but primarily to regular customers who have been in large numbers for a long time with multiple marketing methods. In marketing its products, Nukida Jati also carries out promotions to become increasingly recognized by the wider community.

"Yes, the promotion is via cellphones, whether via Facebook or what it is. It is being photographed and then uploaded. There will be something interesting, definitely contact. Now, the promotion goes through it faster. If there is a participating exhibition event, it will help marketing. "

However, until now, Nukida Jati does not have a brand. Business owners feel that there is no significant influence on the presence or absence of their products. According to him, the most crucial thing in business is that sales can increase. Thus, superior regional products' potential has not been maximally utilized because there is no brand strength in the product. The availability of stock items is also a point of concern for Nukida Jati. Usually, companies always provide a stock of goods as a backup if, at any time, there is a product order that must be done suddenly. The location of MSMEs Nukida Jati, which is on the border between Padangan District and Cepu District, is a strategic area because many immigrants have crossed the site. It is an opportunity for Nukida Jati to increase its sales.

Financial condition is one of the most critical factors for a related business in obtaining capital, using business costs, and calculating profits. The capital of Nukida Jati MSMEs only comes from business owners, so that it is constrained. Limited financial cause MSME Nukida Jati to have trouble in increasing production capacity to meet demand. Based on observations, it was found that MSMEs Nukida Jati did not yet have a financial report book, recording orders by consumers and sales notes.

"There are no books. At least I just recorded taking so many sales. I am fortunate that there are no bookkeeping rules. You have to be rich, but it 
does not work. At most, how many orders will I take, how much will I produce, what costs? There is no complete bookkeeping. "

The production function in a company consists of turning input activities into output in teak wood handicraft products. Research and development generally focus on new products before competitors implement them, with increased marketing objectives. Nukida Jati carries out research and development by making various designs depending on market demand or ideas from the owner. Economic conditions significantly affect the continuity of the teak handicraft business, especially in Nukida Jati.

Economic growth factors can affect the running of a business. If the income level increases, it will also increase people's purchasing power. Political factors, government policies, and laws greatly influence the sustainability of a company. Also, the government has an essential role in advancing business. As in Nukida Jati, local governments play a role in the progress of MSMEs by holding exhibition events to marketing. Changes that occur in society, culture, and the environment affect both companies and consumers. So the company must be careful in understanding the differences that exist to take advantage of current opportunities and avoid threats that arise. The environment of Nukida Jati is very supportive of the existence of a wood handicraft business where there are many raw materials available in the area.

The use of technology in a company hasindeed been encountered. By following the opportunities and threats for the company. Based on the interview results, it can be determined development of technology, a business will progress and develop. The more businesses that have sprung up, the tighter the competition between companies will be. Nukida Jati has to face the average competition that is still in its business area. Hence, a strategy needs to be done so that the business it runs is sustainable.

Identification of internal factors is made to determine the strengths and weaknesses that exist in a company. In identifying internal factors, several aspects consist of management, marketing, finance, production, research, and development. Based on the results of the interview, it is found that the internal factors which are strengths for Nukida Jati are:

a. Have a better product quality

b. The designs and types of products vary

c. Fast packaging and delivery times

d. There is stock availability

e. Have a competitive price

f. Promoting through the internet media

g. Strategic business location

h. A functional relationship between artisans, suppliers, and business owners

Internal factors that become weaknesses for MSMEs Nukida Jati are:

a. Does not have a brand on the product

b. Items are easily damaged during delivery

c. Financial records are still pure

d. It has limited business capital

e. The use of technology as a promotional medium is not optimal

Implementation of identifying external factors in this company aims to identify that external factors that become opportunities for MSMEs Nukida Jati are: 
Munawaroh, I., Nuraina, E. \& Astuti, E. (2021). Analisis Strategi Bisnis Untuk Mencapai Keunggulan Kompetitif ...

a. Internet-based trading

b. Teak wood crafts are a superior product

c. Public interest in woodcrafts is increasing

d. The breadth of marketing both at home and abroad

External factors that pose a threat to Nukida Jati MSMEs include:

a. The number of similar product businesses

b. Price competition between competing companies

c. Raw materials are running out

d. Unstable economic conditions

The IFE matrix helps identify the company's internal conditions, namely its strengths and weaknesses. The results of weighing the strengths and weaknesses of Nukida Jati MSMEs resulted in 33.5 with a total score of the IFE matrix of 2.88. These results indicate that Nukida Jati MSMEs are in an average position or relatively stable. Knowledge of its strengths and weaknesses helps increase sales and minimize deficiencies in the business.

The EFE matrix helps identify the company's external conditions, namely the opportunities and threats. The results of weighing the opportunity and threat factors of the Nukida Jati MSMEs obtained 22.5, with a total EFE matrix score of 3.18. These results indicate that Nukida Jati MSMEs have an excellent res- ponse to the opportunities and threats that exist. After knowing the total score on the IFE matrix and the EFE matrix, an IE matrix analysis is carried out to determine the position of Nukida Jati MSMEs. This step was taken to determine the alternative strategies that could be applied. The IE matrix is structured based on two key dimensions. The horizontal axis of the IE matrix shows the total score of the IFE matrix, while the vertical axis of the IE matrix shows the total score of the EFE matrix. Figure 2 shows the results of the IE matrix analysis at Nukida Jati MSMEs.

Tabel 1 Total IFE Matrix

\section{Strong Average Weak}

\begin{tabular}{ccc|c|c|c|} 
Total & \multicolumn{4}{c}{3} & \multicolumn{2}{c}{2} & \multicolumn{1}{c}{1} \\
\cline { 3 - 6 } EFE & High & 4 & I & II & III \\
\cline { 3 - 6 } Matrix & Moderate & 3 & IV & V & VI \\
\cline { 3 - 6 } & Low & 2 & VII & VIII & IX \\
\cline { 3 - 6 } & & & &
\end{tabular}

Based on the IFE and EFE matrices, the total IFE score is 2.82, and the EFE total score is 3.18. The mapping is done on the IE matrix, which shows the results of

MSMEs Nukida Jati in cell II. The alternative strategies applied to Nukida Jati MSMEs based on the strengths, weaknesses, opportunities, and threats obtained from the identification process of internal and external factors are presented in Table 1 
Table 2 SWOT Matrix

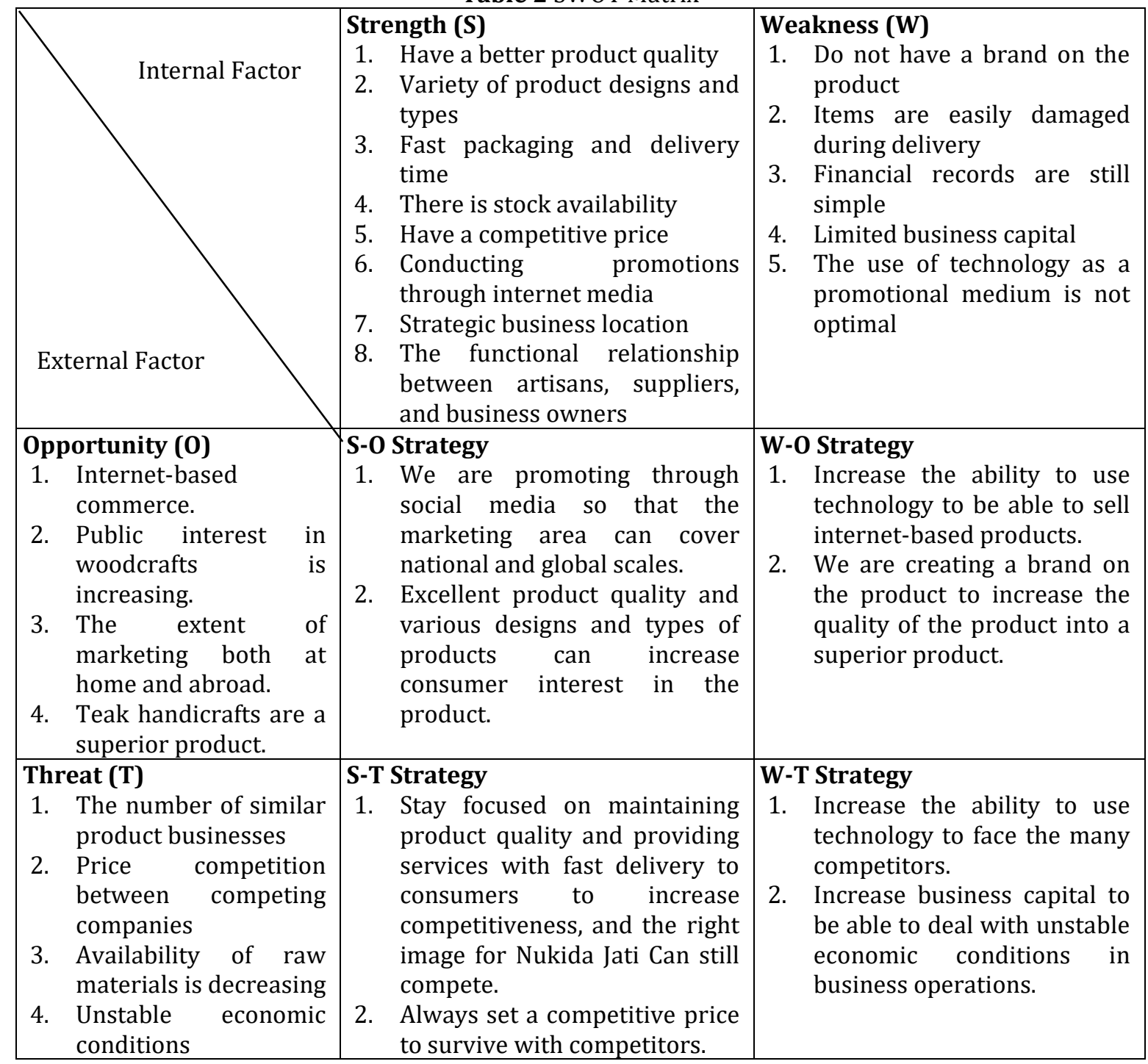

Based on the strengths, weaknesses, opportunities, and threats of MSMEs Nukida Jati, a SWOT matrix analysis is carried out to be able to survive in the face of increasingly fierce competition, and produce four strategies, namely:

\section{a. S-O strategy}

The S-O strategy is carried out to take advantage of current opportunities. The S-O strategy at Nukida Jati MSMEs includes maintaining and improving product quality to increase consumer interest. Product quality that is already good must be preserved and enhanced by adding product innovations such as adding new shapes and colors. So that by innovating products, customers are more interested in increasing sales, and the company's competitiveness can increase. That statement aligns with Adi \& Oktarina (2018) and Afwan \& Suryono (2019) statements, which state that product quality positively affects purchasing decisions.

Also, promotion through social media must be further improved to expand the marketing 
area from what has been previously reached. By utilizing social media, consumers can easily purchase products anywhere, anytime, without coming to the place of business. Customers can easily find out what products from Nukida Jati are offered. That statement aligns with Mursito (2019) ideas and Setiawati \& Widyartati (2017), which states that digital marketing can increase product sales volume, increasing company profits.

\section{b. W-O strategy}

The W-O strategy is carried out by taking advantage of existing opportunities. The W-O strategy includes increasing the ability to use technology so that Nukida Jati MSMEs can maximize sales by using the internet.

Another strategy that needs to be applied is the manufacture of brands for Teak Nukida handicraft products. The strength of the brand on the product is very influential in making sales. The existence of a brand on the product will make it easier for MSME Nukida Jati to carry out marketing or promotional activities, get protection for product characteristics, and create consumer loyalty. In line with that, Kristianingsih et al. (2018), Pratama \& Santoso (2018), Resmawa (2017), and Saing et al. (2019) states that the company's brand image can increase product sales.

\section{c. S-T strategy}

The S-T strategy utilizes the existing strengths in the company to avoid various threats that arise. Some of the resulting strategies are maintaining product quality and providing excellent service to consumers, thereby creating consumer confidence in Nukida Jati products to compete with competitors.
Another strategy that needs to be done is always to set competitive prices by paying attention to product prices from competitors. By consistently providing competitive prices, it will attract consumer interest so that the business carried out will survive the actual competition. In line with that, Agusri (2019) and Halin et al. (2017) state that determining the price of a company's product has a positive effect on sales volume.

\section{d. W-T strategy}

The $\mathrm{W}-\mathrm{T}$ strategy aims to reduce or minimize the weaknesses that exist in the company to avoid emerging threats. Nukida Jati MSMEs must be able to increase human resources that are still lacking in the use of technology. Also, Nukida Jati MSMEs must raise business capital, which is also a disadvantage of Nukida Jati by innovating products. Sales will increase, and the profits obtained will also increase. By having sufficient capital and proper financial management, Nukida Jati can run a business well and compete by implementing the right strategy. This is in line with Berkova et al. (2017), who documented that corporate culture to invest in human resources, develop employee learning environments, share information, or encourage employees' innovative behavior is closely related to improving the company's financial performance.

Based on the analysis of some of these strategies, the most advantageous position for MSMEs Nukida Jati is to optimize the strength and opportunities of the company because based on the combination of IFE and EFE matrices, the company is in quadrant 1 . The strategy that can 
be chosen is the S-O strategy. By considering the strengths of their products and opportunities to open a more comprehensive market through digital marketing, companies can choose a related diversification strategy. This is under the condition of a company that produces handicrafts with various product specifications according to customer orders by utilizing the same raw materials.

This is in line with Rahmanto \& Rahayu (2017), which states that when a company is in quadrant 1 , it can choose one of the following strategies:
a. Market development
b. Market penetration
c. Product development
d. Forward integration
e. Backward integration
f. Horizontal integration
g. Related diversification

\section{CONCLUSION}

Based on the analysis of internal and external factors, Nukida Jati MSMEs are average and exceptionally durable. Meanwhile, the external conditions of Nukida Jati MSMEs have an excellent response to opportunities and threats for Nukida Jati MSMEs. So the right strategy to use is related diversification.

The limitation of this research is that it only measures business strategy using matrix and SWOT analysis. The research object is only in one location, namely MSMEs Nukida Jati, so there is no comparison to strategy implementation other than the lack of information availability. For future researchers, if doing this type of research is expected to add to other data analysis techniques and use a different research location, it can compare and reinforce existing research results.

\section{REFERENCE}

Abdillah, M. B., Hakim, R. M. A., Damiri, D. M., \& Zahra, F. (2017a). Business Strategy Analysis On SMEs Bamboo Crafts In Bandung City. Jurnal AdBispreneur, 2(3), 227-242. http://jurnal.unpad.ac.id/adbispreneur/article/v iew/16491

Abdillah, M. B., Hakim, R. M. A., Damiri, D. M., \& Zahra, F. (2017b). Business Strategy Analysis On SMEs Bamboo Crafts In Bandung City. Jurnal AdBispreneur, 2(3), 227-242.

Adi, K., \& Oktarina, F. (2018). Pengaruh Kualitas Produk Dan Harga Terhadap Minat Beli Pelanggan Pada Perusahaan Mebel Ud. Lumintu Tegalsari - Ambulu. Majalah Ilmiah DIAN ILMU, 16(1), 48-59. https://doi.org/10.37849/midi.v16i1.63

Afwan, M. T., \& Suryono, B. S. (2019). Analisis Pengaruh Kualitas Produk, Persepsi Harga dan Kualitas Pelayanan terhadap Keputusan Pembelian dengan Citra merek Sebagai Variabel Intervening (Studi pada Konsumen Mebel Madina di Kota Banjarnegara). Diponegoro Journal of Management, 8(1), 1-13.

Agusri. (2019). Pengaruh Harga Terhadap Volume Penjualan Pada Mebel Sinar Barokah Tanjung Karangan Kabupaten Muara Enim. Jurnal Media Wahana Ekonomika, 16(3), 192-203.

Berkova, I., Adamova, M., \& Nyvltova, K. (2017). Relationships Between Financial and Learning and Growth Perspectives in BSC. Acta Universitatis Agriculturae et Silviculturae Mendelianae Brunensis, 65(6), 1841-1850. https://doi.org/10.11118/actaun201765061841

Halin, H., Wijaya, H., \& Yusilpi, R. (2017). Pengaruh Harga Jual Kaca Patri Jenis Silver Terhadap Nilai Penjualan Pada Cv. Karunia Kaca Palembang Tahun 2004-2015. Jurnal Ecoment Global, 2(2), 49-56. https://doi.org/10.35908/jeg.v2i2.251

Hidayat, T. (2016). Formulasi Strategi Bisnis dalam Upaya Meningkatkan Daya Saing Industri Batik "Mliwis Putih" di Desa Sobontoro, Balen, Bojonegoro. Jurnal Edutama, 3(1), 21-30.

Januarwati, R., \& Poernomo, E. (2014). Analisis Strategi Bisnis Usaha Mikro Kecil Menengah Toko Bunga "Cindy" di Jl. Kayoon Utara No.12 GentengkaliSurabaya. Jurnal Bisnis Indonesia, 5(2), 155-164.

Kristianingsih, W. D., Wibowo, S. B., \& Astuti, E. (2018). Studi Korelasi Brand Awareness Dan Kualitas Produk Terhadap Keputusan Pembelian Batik Tulis Di Batik Murni Madiun. FIPA: Forum Ilmiah Pendidikan Akuntansi, 6(2), 1-6. http://prosiding.unipma.ac.id/index.php/FIPA/a 
Munawaroh, I., Nuraina, E. \& Astuti, E. (2021). Analisis Strategi Bisnis Untuk Mencapai Keunggulan Kompetitif ...

rticle/view/578

Mursito, H. (2019). Sosial Media Sebagai Upaya Peningkatan Penjualan Produk UKM (Studi Kasus di SMESCO Jakarta). Pekobis: Jurnal Pendidikan, Ekonomi, Dan Bisnis, 4(2), 41-47. https://doi.org/10.32493/pekobis.v4i2.p4147.3949

Pratama, D. W., \& Santoso, S. B. (2018). Pengaruh Citra Merek, Kualitas Produk dan Harga Terhadap Keputusan Pembelian melalui Kepercayaan Konsumen pada Produk Stuck Original. Diponegoro Journal of Management, 7(2), 1-11.

Rahmanto, P. N., \& Rahayu, M. (2017). Perumusan Strategi Bisnis Pada Usaha Kecil Dan Menengah (Studi Pada Dea Cake And Bakery). Jurnal Ilmiah Mahasiswa FEB, 2(1), 68-70.

Resmawa, I. N. (2017). Pengaruh Brand Image dan Product Knowledge terhadap Purchase Intention dengan Green Price sebagai Moderating Variabel pada Produk the Body Shop di Surabaya. Jurnal Aplikasi Manajemen, Ekonomi Dan Bisnis, 1(2), 111.

Saing, S. M., Alam, S., \& Maming, J. (2019). Pengaruh
Strategi Pemasaran Dan Brand Image Terhadap Kepuasan Dan Keputusan Pembelian Produk "Kita" Perum Bulog Subdivre Makassar. Hasanuddin Journal of Management, 1(1), 1-8. https://doi.org/10.2991/icame-18.2019.71

Sari, D. A., \& Suprapto, R. (2018). Strategi Peningkatan Daya Saing UMKM Pengolahan Ikan Melalui Analisis SWOT. Stability: Journal of Management and Business, 1(2), 110-122. https://doi.org/10.26877/sta.v1i2.2857

Setiawati, I., \& Widyartati, P. (2017). Pengaruh Strategi Pemasaran Online Terhadap Peningkatan Laba UMKM. Seminar Nasional Dan Call for Paper 2017 Strategi Pengembangan Sumber Daya Manusia Melalui Publikasi Jurnal Ilmiah Dalam Menyikapi Permenristekdikti RI No.20 Tahun 2017, 1, 343347.

file://C:/Users/BAYU/Downloads/Documents/ 263-760-1-PB.pdf

Umar, A., Sasongko, A. H., Agusman, G., \& Sugiharto. (2016). Analisa Swot Pada Bisnis Rumahan, Studi Kasus Pada Bisnis Laundry Kiloan. Buletin Bisnis Dan Manajemen, 2(2), 84-100. 